\title{
Classroom Communication Climate and Communicative Linguistic Competence of EFL Learners
}

\author{
Danebeth Tristeza Glomo-Narzoles \\ Department of Languages and Literature, AMA International University-Bahrain, Kingdom of Bahrain
}

\begin{abstract}
This study aimed to determine the classroom communication climate and communicative linguistic competence of EFL students who are in their senior years in a university. This is a descriptive method of research which intended to find out the correlation between classroom communication climate and communicative linguistic competence. A validated questionnaire on the perceived classroom communication climate was used. To measure the students' proficiency in the English language, a validated 100-item communicative linguistic assessment was given. The data gathered from the study were subjected to descriptive statistics such as means and standard deviations; and inferential statistics which included t-test, ANOVA, and Pearson r Correlation, all set at .05 alpha. The findings revealed that the students perceived the classroom communication climate as supportive. This supportive communication climate means that the communication atmosphere in the classroom allows students' flexibility, experimentation, and creativity. Understanding and listening to the students, respecting their feelings and acknowledging their individual differences, making them feel secure, and avoiding control in the classroom are the teacher attributes that corroborate a supportive communication climate in the classroom. Moreover, the teacher is also a free of hidden motives and honest but with a few limitations. The students' communicative linguistic competence was proficient. Programme enrolled and sex were not significant correlates of the perceived type of classroom communication climate and students' communicative linguistic competence. There was a significant relationship between classroom communication climate and communicative linguistic competence.
\end{abstract}

Index Terms - communication climate, classroom environment, communicative linguistic competence, EFL learners

\section{INTRODUCTION}

Teachers of English as Foreign Language (EFL) have been so engrossed with curriculum innovations to the point that the actual delivery of classroom instruction had been neglected. A lot of researches have been conducted to determine the communicative linguistic competence correlates and one of these is the communication climate in the classroom.

Communication climate refers to the emotional tone of a relationship which may either be a parent-child, employerboss, or teacher-student. There are classrooms in which the environment is friendly and conducive to learn while some are cold and tensed, even hostile.

Jack Gibb (1961) pointed out two opposite communication climates which are the supportive and defensive. Supportive climates enforce people. On the other hand, defensive climates put people always on guard, which results precipitate offensive actuations, words, and tone of the speaker. Communication climates which are supportive emanate from behaviors of equality, description, spontaneity, problem orientation, provisionalism, and empathy. Defensive communication climates emerge from superiority, evaluation, strategy, control, certainty, and neutrality.

Supportive communication climate is apparent when a head or immediate superior empowers subordinates through flexibility, experimentation, and creativity. Moreover, this communication climate is exemplified by a head who understands and listens to employee concerns, regards employee's worth and viewpoints, does not try to make employees feel inadequate and belittled, does not impose his or her position to manipulate situations, respects the status of other people, communicates freely without ulterior motives, and demonstrates honesty in words and in deeds (Costigan and Schmeidler, 1984).

Neutral communication climate is evident when the supervisor lacks care and respect for the identity and uniqueness of his people. He neither shows respect for the other's value nor gives amenability to the opinions, decisions and free willingness of others. Simply speaking, this climate is described by a supervisor who neglects his time for his people, does not give his availability to listen to the employees, and does not demonstrate a genuine care and concern for his people (Gibb, 1961).

A communication climate which is non-supportive is shown by a head or supervisor who is demanding and discriminating. This superior does not listen to subordinates' explanations, acts in domineering ways, takes up to alter other people, manipulates the employees, complicates and misunderstands what is said, constantly reminds people who is in charge, keenly supervises the work, and makes employees feel inadequate and incapacitated. 
In the context of EFL learning, Krashen $(1981,1982)$ theorized that people acquire second or foreign language structures in a predictable order only if they obtain comprehensible input, and if their anxiety is low enough to allow input to their minds.

According to Krahen (1981), the affective filter hypothesis has something to do with variables which pertain to emotions such as anxiety, motivation, and self-confidence. The said facets are deemed vital because these may either hamper or encourage input from reaching the language acquisition device (LAD). If the emotional filter blocks some of the understandable elements, less input is perceived by the learner's LAD; in so doing, less language is accumulated. Apparently, a favorable affective situation escalates the input.

In the same vein, EFL educators must comprehend that a supportive communication climate in the classroom fosters learning that eventually heightens the enjoyment of learning, increases self-esteem and blends self-awareness with an increase in the proficiency as students learn English.

\section{A. Theoretical Background}

Littlewood (1984) contends that one of the characteristics of a positive classroom environment is a relaxed atmosphere. A classroom with a defensive communication climate, anxiety obstructs the learning process which would eventually lead to learners' feelings of reluctance especially in airing their sentiments. In such case, the teacher should not be a cause of the apprehensions of the students since most often, teachers who are fond of finding faults and are judgmental instigate a high anxiety level among students in EFL classes.

Gibb (1961) indicated that if persons strive to be more cognizant of the of the elements evident in both supportive and defensive climates and how these relate on communication, they will be able to deduce other people's reactions and actuations thereby promoting relationships with real and open communication.

According to the model of Getzels and Thelen (1960), a class, with various personality needs, role expectations, and classroom climates are determinants of group behaviors which include the learning process. These climates develop also as an upshot of the teacher's transactional style or the manner in which role necessities and personality needs were balanced (Deng, 1992).

The responsibility of creating a positive communication in the classroom, where issues are openly recognized and managed in a way that promotes learning, lies on the hands of the EFL educators.

To what extent is classroom communication climate associated with the communicative linguistic competence of students? Classroom communication climate and communicative linguistic competence are current major concerns but have not been research-explored very much yet. Hence, this study.

Figure 1 graphically shows the framework of the study.

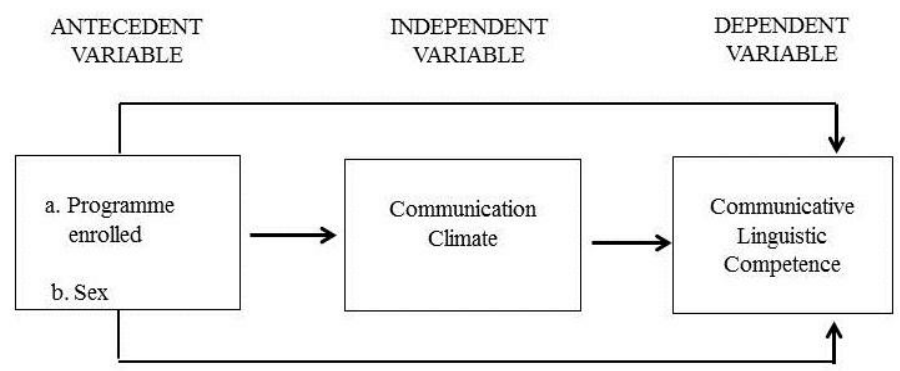

Figure 1. Communication Climate and Communicative Linguistic Competence of EFL Learners

\section{B. Objectives}

This study aimed to determine the classroom communication climate and communicative and communicative linguistic competence of EFL students who are in their senior years in a university.

Specifically, this was conducted to shed light to the following questions:

1. What is the perceived type of classroom communication climate and level of communicative linguistic competence of students as an entire group and when classified according to programme enrolled and sex?

2. Is there a significant difference on the perceived type of classroom communication climate and level of communicative linguistic competence of students classified according to programme enrolled and sex?

3. Is there a significant relationship on the students' perceived type of classroom communication climate and their communicative linguistic competence?

\section{Hypotheses}

Based on the aforementioned problems, the following null hypotheses were advanced:

1. There is no significant difference on the perceived type of classroom communication climate and level of communicative linguistic competence of students classified according to programme enrolled and sex.

2. There is no significant relationship on the students' perceived type of classroom communication climate and their communicative linguistic competence. 


\section{Significance}

Results of this study may serve as an eye-opener to the university administrators that they may see to it that the English curriculum offered to the EFL learners is really designed to develop their communicative and linguistic skills. Through this, the students will be properly trained, thus enhancing their competence in the foreign language. Moreover, the administrators may conduct programs and activities that may aid in creating a classroom environment conducive for the students to keep them abreast with the current trends in the English language.

The English teachers may be reminded that their sincere and committed efforts in creating a supportive classroom communication climate will surely be an important factor in helping their students gain competence in English.

\section{METHODS}

\section{A. The Participants}

The participants of this study were 180 university students, who are in their senior years, chosen through stratified random sampling. The participants comprised one-third of the total population of the senior students.

The students were categorized according to the programme in which they are enrolled (business, computing, and engineering); and sex (male or female).

\section{B. Data Collection Instruments}

Communication Climate Inventory. A 24-item rating scale using Likert format patterned from the Communication Climate Inventory by Costigan and Schmeidler (1984) was utilized. The items are descriptive of the type of communication between the EFL teachers and the students in the classroom. Communication climate may range from highly non-supportive to highly supportive.

Numerical values were assigned to the positively stated statements: 5 for strongly agree, 4 for agree, 3 for uncertain, 2 for disagree and 1 for strongly disagree. For negatively stated statements, the scoring values were reversed. Mean scores on the communication climate assessment tool were interpreted using the scale below:

$\begin{array}{cl}\text { Scale } & \text { Description } \\ 4.20-5.00 & \text { Highly supportive } \\ 3.40-4.19 & \text { Supportive } \\ 2.60-3.39 & \text { Neutral } \\ 1.80-2.59 & \text { Non-supportive } \\ 1.00-1.79 & \text { Highly Non-Supportive }\end{array}$

The following interpretations, patterned from Costigan and Schmeidler (1984) and Gibb (1961), were utilized to describe the classroom communication.

A supportive communication climate is shown by a teacher who allows flexibility, experimentation, and creativity. $\mathrm{He}$ or she understands and listens to students' problems and respects their feelings and values. As such, he or she does not let the students feel inadequate and does not use his or her authority in the classroom to manipulate situations. His or her communications do not have ulterior motives; he or she projects honesty but with a few limitations.

A neutral communication climate is characterized by a teacher who lacks concern for the individuality of his or her students. He or she does not lend a listening ear to students who would like to share their opinions and sentiments. This means that a teacher does not allot his available time to show his or her genuine care and concern to the students.

A non-supportive communication climate is demonstrated by a teacher who is critical and judgmental. As such, he or she will not accept explanations from students. He or she projects a very authoritative manner and undertakes to modify other people's viewpoints, manipulates the students and most of the time misunderstands, twists and falsifies what is said. He or she reminds students that he or she is in charge in the classroom, keenly supervises everything in the classroom, makes students feel inferior.

Communicative Linguistic Competence. The instrument used to determine the students' communicative linguistic competence was a validated 100- item Communicative Linguistic Assessment that had undergone pilot testing with $\mathrm{r}=$ 0.834 .

The test contains eight parts: Part I, Language Usage, 20 items; Part II, Pronouns, 10 items; Part III, Verbs, 10 items; Part IV, Correct Usage, 10 items; Part V, Tense, Aspect and Voice, 10 items; Part VI, Vocabulary, 10 items; Part VII, Analyzing fact and opinion statements, 10 items; -Part VIII, Verbal Reasoning, 10 items and Part IX, Reading Comprehension, 10 items. To determine the students' communicative linguistic competence, this scale was employed:

$\begin{array}{ll}\text { Scale } & \text { Description } \\ 81-100 & \text { Extremely Proficient } \\ 61-80 & \text { Highly Proficient } \\ 41-60 & \text { Proficient } \\ 21-40 & \text { Fairly Proficient } \\ 1-20 & \text { Poor }\end{array}$

\section{Data Analysis}


The descriptive statistics employed included mean and standard deviation. For inferential statistics, t-Test, Analysis of Variance (One-Way ANOVA) and Pearson Product-Moment Coefficient of Correlation (Pearson's r) were utilized. The data gathered from the study were subjected to certain computer-processed statistical analysis using the Statistical Package for Social Sciences (SPSS) program.

\section{RESULTS}

TABLE 1.

ClassRoom COMMUNiCATION Climate

\begin{tabular}{lcll}
\hline Category & $\underline{\mathrm{M}}$ & Description & $\underline{\text { SD }}$ \\
\hline Entire Group & 3.45 & Supportive & .44 \\
A. Programme Enrolled & & & \\
$\quad$ Business & 3.56 & Supportive & .52 \\
$\quad$ Computing & 3.52 & Supportive & .56 \\
$\quad$ Engineering & 4.18 & Supportive & .51 \\
B. Sex Female & 4.21 & Highly supportive & .48 \\
$\quad$ Male & 4.18 & Supportive & .58 \\
\hline
\end{tabular}

Table 1 shows that as an entire group, the students perceived type of classroom communication climate as "supportive".

This supportive communication climate means that the communication atmosphere in the classroom allows students' flexibility, experimentation, and creativity. The teacher understands and listens to the students' problems and respects their feelings and values. As such, the teacher does not try to make the students feel inferior and does not use status to control situations. The teacher is also a free of hidden motives and honest but with a few limitations.

When grouped as to the programme enrolled, students perceived the classroom communication climate to be "supportive. As to sex, females regarded communication climate in the classroom to be highly supportive while males perceived it to be "supportive".

TABLE 2.

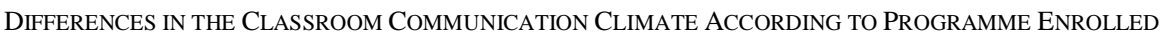

\begin{tabular}{lcrlrl}
\hline & $\begin{array}{l}\text { Sum of } \\
\text { Squares }\end{array}$ & df & $\begin{array}{l}\text { Mean } \\
\text { Square }\end{array}$ & F & Sig. \\
\hline Between Groups & 1.531 & 3 & .422 & 1.854 & .145 \\
Within Groups & 45.623 & 176 & .259 & & \\
Total & 47.054 & 179 & & & \\
\hline
\end{tabular}

As shown in Table 2, there was no significant difference on the perceived classroom communication climate when the students were classified as to programme enrolled $(\mathrm{F}=1.85, \mathrm{df}=3)$. The mean scores ranged from 3.52 to 4.18 , all are described as "supportive".

This means that regardless of the programme enrolled, students regard the classroom communication climate to be positive as exemplified by the EFL teacher who is warm, friendly, approachable, and supportive to the learning needs of the students.

TABLE 3.

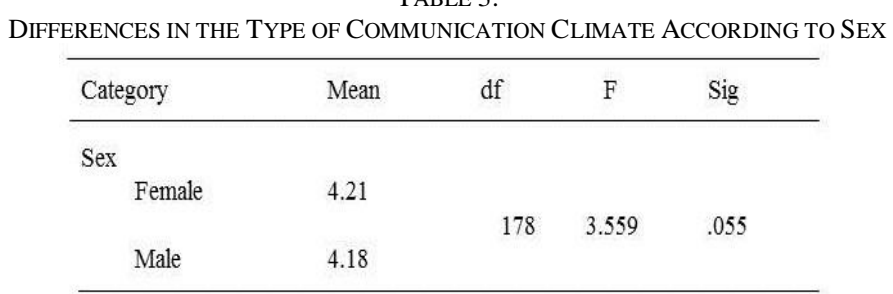

Table 3 shows that results of the t-test revealed that there was no significant difference on the perceived type of communication climate when students are grouped according to sex. Both the female and the male respondents perceived their classroom communication climate to be supportive. 
TABLE 4.

COMMUNiCATIVE LINGUISTIC COMPETENCE OF STUDENTS

\begin{tabular}{llcll}
\hline \multicolumn{2}{l}{ Category } & $\underline{\mathrm{M}}$ & Description & $\underline{\text { SD }}$ \\
\hline A. Entire Group & 59.60 & 8.85 & Proficient \\
B. Programme enrolled & & & \\
& Business & 57.58 & 10.25 & Proficient \\
& Computing & 62.35 & 10.52 & Proficient \\
& Engineering & 64.00 & 6.91 & Highly proficient \\
C. Sex & & & & \\
& Female & 57.95 & 10.85 & Proficient \\
& Male & 62.84 & 6.61 & Highly proficient \\
\hline
\end{tabular}

The communicative linguistic competence of students was determined in this study. Table 4 shows that as an entire group, the students' communicative linguistic competence was "highly proficient" $(\mathrm{M}=59$. 60; $\mathrm{SD}=8.85)$.

When categorized as to the programme enrolled, both the business $(\mathrm{M}=57.58 ; \mathrm{SD}=10.25)$ and computing $(\mathrm{M}=62.35$; $\mathrm{SD}=10.52)$ students are "proficient" while the engineering $(\mathrm{M}=64.00 ; \mathrm{SD}=6.91)$ students are "highly proficient".

TABLE 5.

DifFERENCES IN THE LEVEL OF COMMUNICATIVE LINGUISTIC COMPETENCE ACCORDING TO PROGRAMME ENROLLED

\begin{tabular}{lcrlll}
\hline & $\begin{array}{l}\text { Sum of } \\
\text { Squares }\end{array}$ & df & $\begin{array}{l}\text { Mean } \\
\text { Square }\end{array}$ & F & Sig. \\
\hline Between Groups & 1.423 & 3 & .480 & 1.760 & .168 \\
Within Groups & 45.526 & 176 & .270 & & \\
Total & 46.157 & 179 & & & \\
\hline
\end{tabular}

As exemplified in Table 5, there was no significant difference on the level of communicative linguistic competence when the students were classified as to programme enrolled $(\mathrm{F}=1.76, \mathrm{df}=3)$. The business, engineering, and computing students, who are in their senior years, are proficient in the English language.

TABLE 6.

DifFERENCES IN THE LEVEL OF COMMUNICATIVE LiNGUISTIC COMPETENCE ACCORDing to SEX

\begin{tabular}{llllll}
\hline & Category & Mean & df & F & Sig. \\
\hline Sex & & & & & \\
& Female & 3.05 & & & \\
& Male & 3.15 & & & \\
& & & & & \\
\hline
\end{tabular}

Table 6 shows that there is no significant difference on the level of communicative linguistic competence of students when grouped as to sex. Both female and male students demonstrated proficiency in EFL.

TABLE 7.

RELATIONSHIP OF CLASSROOM COMMUNICATION CLIMATE AND COMMUNICATIVE LiNGUISTIC COMPETENCE

\begin{tabular}{lll}
\hline & & Communication Climate \\
\hline Communicative & Pearson $\mathrm{r}$ & $.749 * *$ \\
Linguistic & Sig. (2-tailed) & .000 \\
Competence & $\mathrm{N} \quad 180$ \\
\hline \multicolumn{3}{c}{$* \mathrm{p}<.05$}
\end{tabular}

The results of the correlational analysis using Pearson $r$, revealed that a significant relationship exists between the classroom communication climate and communicative linguistic competence of the EFL learners. Table 7 shows that the $\mathrm{r}$ value is 0.749 , significant at .05 . Thus, the type of classroom communication climate is a contributing factor to the students' communicative linguistic competence.

This significant relationship had been strengthened by Walberg and Anderson (1968), Walberg's (1971), Chatiyanonda (1978), Eash and Rasher (1978), White (1986), McIntosh (1991), Dietrich and Bailey (1996), Freiberg(1998), Bennet (2001), Yi (2010), and Sun (2012). These researchers asserted that the higher the student satisfaction with the classroom climate, the higher the academic achievement would be.

However, having advanced that classroom climate is not significantly related with the student's achievement, Simmons (1989), Deng (1992), Dunn and Harris (1998), opposed the results of the present investigation.

\section{DisCUSSION AND CONCLUSION}


The University students perceive their EFL classroom communication climate to be very conducive thus, a major contributing factor for them to be proficient in their communicative linguistic competence. This study has proved that classroom environment, in which communication climate is a part of, has clearly been associated with student's achievement.

Braid's theory (1993), which contends that learner's linguistic environment, is a major contributing factor to language acquisition, attitude toward the language, and even the way one perceives the language, shed a positive light on the results of the present investigation.

In addition, results of the study had been corroborated by Ferguson, Dorman, and Adams (2000) who posited that a significant relationship persists between the perceptions of students of their classroom climate and academic performance. They claimed that students learn better when they perceive their learning environment positively.

Likewise, Scott-Jone and Clark (as cited in Caruthers, 1994) bear out that the classroom situation in which the learning process occurs can either enrich or write off the attitudes that lead to progress, and that academic literacy is dependent on more than singular abilities and capabilities.

Communicative Language Teaching Approach (CLT) which advanced that classroom should be made into a social environment, reflective of a community where positive student-teacher relationship occurs, agrees with the result of the study (Piepho, 1981).

Stern's (1970) Person- Environment Congruence Theory, based on Murray's model, proposed that harmonious correlations between individual needs and environmental facets lead to improved learning outcomes.

Moreover, Stern (1980) posited that the success of the language course is less dependent on the materials, methods, techniques and linguistic analyses. Language learning depends more on the positive interactions and relationships that develop among the people in the classroom.

As added by Canfield and Wells (1994), students should feel safe and encouraged in the classroom. If the students discern that they are supported, valued, recognized and accepted, their potentials will be unfurled all by themselves without hesitation.

The teacher facilitates the teaching-learning process. However, a positive communication climate in the class is contributed by language teachers who help the students view language learning positively, guide the learners in every step of the way, decentralizes control and acts in a democratic manner by nurturing meaningful communication, curiosity, and insight (Rogers, 1969).

As stipulated Walberg's (1971) model, emphasis was given to environments which were associated with the students' dispositions and the type of classroom climate in predicting learning outcomes. Likewise, in the present investigation, students' positive perception of their classroom communication climate had been attributed to their communicative linguistic competence proficiency.

The findings of the investigation corresponded to the research conducted by Dorman, Adams and Ferguson on the associations between classroom psychosocial environment in mathematics classroom and academic efficacy wherein simple and multiple correlation analyses revealed statistically significant correlations between classroom environment dimensions and academic efficacy. Results showed that classroom environment relates positively with academic efficacy.

Similarly, the findings agreed to the proponents of the Communicative Language Teaching Approach (CLT) who advanced that classroom should be made into a social environment, reflective of a community where positive studentteacher relationship occurs (Piepho, 1981). Moreover, Montessori (Microsoft @ Encarta ® Reference Library 2005) asserted on giving children freedom in a specially prepared environment, under the guidance of a trained director.

Language learning is a collaborative effort of the things and people surrounding the learners. Theory of Realubit (1993) claims that the child, if surrounded by a speaking environment in a language, the child will speak in that language automatically. Thus, if Arabs speak in English fluently, it is because the conducive classroom climate for English is provided for them. To speak a language, particularly English, there should be an environment for it. Books, textbooks, magazines, periodicals, radio, television, and other materials in English should flood the whole environment of the learner inasmuch as even innately mapped program for behavior depends for its realization upon the speech environment. Given the linguistic environment, there is no doubt a non-English speaker will learn the language with ease and accuracy.

Thompson (1997) and Finocchiaro (1998) likewise stress that students should be provided a very good classroom climate that will enable them to learn English as a foreign language.

The above-mentioned theories and related studies have corroborated the findings of the present investigation that indeed, classroom communication climate is a significant correlate of the EFL learners' communicative linguistic competence.

The university students assessed their classroom communication climate to be very conducive for them to learn and master the basic skills of the English language. The proficiency in the field of English is probably attributed to their supportive EFL teachers who maintained open lines of communication which eventually catered to the students' needs in learning.

Indeed, teachers who are at the warm, approachable, friendly, helpful and supportive and strict yet with compassion are regarded to create a positive classroom climate. 
On the other hand, students do not respond well to teachers who criticize students and points out students' frailties. In such case, the attainment of the intended learning outcomes in the EFL course is affected by how supportive and nonsupportive students perceive their teachers to be.

Thus, EFL educators are expected to contribute to an effective classroom climate, to execute the English curricula enhances not only the academic facet but also the affective and social aspects.

\section{REFERENCES}

[1] Anderson, G. \& Walberg, H. (1974). Evaluating educational performance. In H. J. Walberg (Ed.), Evaluating educational performance: A sourcebook of methods, instruments, and examples (pp. 81-98). Berkley, CA: McCutchan.

[2] Braid, F. (1993). Reading on trends and directions in language education. Manila. Philippine Normal College.

[3] Canfield, J. \& H. C. Wells. (1994). One Hundred Ways to Enhance Self-Concept in the Classroom. Boston: Allyn and Bacon.

[4] Caruthers, L. (1994). Power teaching: Principles of Empowerment (Rev. ed.). Kansas City, MO: Mid-continent Regional Educational Laboratory.

[5] Chatiyanonda, S. (1978). An evaluation of the IPST physics curriculum in Thailand. Unpublished doctoral dissertation, Monash University, Melbourne, Australia.

[6] Costigan, J. \& Schmeidler, M. (1983). Communication Climate Inventory. http://www.cps.usfca.edu/ob/studenthandbooks/321handbook/climate.htm

[7] Deng, B. (1992). A multilevel analysis of classroom climate effects on mathematics achievement of fourth-grade students (Clearinghouse No. SE052843). Memphis, TN: Memphis State University. ERIC Document Reproduction Service No. Ed 348 222.

[8] Dietrich, A. \& Bailey, E. (1996). School climate: Common-sense solutions to complicated problems. Bulletin, 16-17.

[9] Dunn, R. \& Harris, L. (1998). Organizational dimensions of climate and the impact on school achievement. Journal of Educational Psychology, 25(2), 100-114.

[10] Eash, M., \& Rasher, S. (1978). Student perceived learning environment in the inner city (Clearinghouse No. UD018103). Toronto, Canada. (ERIC Document Reproduction Service No. ED 152 914)

[11] Ferguson, J., Adams, J., and Dorman J. (2000). A cross- national investigation of students' perceptions of mathematics classroom environment and academic efficacy in secondary schools. Retrieved: August 15, 2004 from www.ex.ac.uk/cimt/ljmtl/dormanj.pdf

[12] Finocchiaro, M. (1965). English as a second language from theory to practice. New York: Regents Publishing Company, Inc.

[13] Getzels, J., \& Thelen, H. (1960). The classroom as a unique social system. National Society for the Study of Education Yearbook, 59, 53-81.

[14] Gibb, J. (1961). Defensive and supportive communication. Journal of communications, 1961, 11, 141-148

[15] Krahen,S.D. (1976). Formal and informal linguistic environments in language acquisition and learning. TESOL Quarterly. $10: 157-168$.

[16] Littlewood,W.T. (1984). Foreign and second language learning. Cambridge: Cambridge University Press.

[17] MacIntosh, J. (1991). Dimensions and determinants of school social climate in schools enrolling middle years students. Retrieved June 12, 2012 from Google Search Engine on the World Wide Web: http://www.ssta.sk.ca/research/school_improvement/91-04.htm\#k

[18] Piepho, H. (1981). Establishing objectives in the teaching of English. London: Longman

[19] Rogers, C. (1969). Freedom to Learn: A View of What Education Might Become. Columbus, OH: Charles E. Merril.

[20] Simmons, R. (1989). Primary students' perceptions of the learning environment as related to teacher training and student achievement. Dissertation Abstracts International, 51(03). (University Microfilms No. AA902195)

[21] Stern,H. (1983). Fundamental concepts of language teaching. Oxford: Oxford University Press.

[22] Sun, Z. (2012). An Empirical Study on New Teacher-student Relationship and Questioning Strategies in ESL Classroom. English Language Teaching, Volume 5. No. 7. 175-183. Retrieved August 4, 2012 from Google Search Engine on the World Wide Web: www.ccsenet.org/elt

[23] Walberg, H. (1971). Models of optimizing and individualizing school learning. Interchange, 3, 15-27

[24] Yi, Fan. (2001). EFL Classroom Management: Creating a Positive Climate for Learning. 128- 137. Retrieved May 6, 2012 from Google Search Engine on the World Wide Web:http://wlkc.nbu.edu.cn/jpkc_nbu

Danebeth Tristeza Glomo-Narzoles was born in Iloilo, Philippines. She finished her Bachelor of Secondary Education (English) in 2003, and Master of Arts in Education (English Language Teaching) in 2006 at West Visayas State University. She earned her degree, Ph.D. in Educational Management in 2009 at the University of San Agustin, Philippines.

Currently, she teaches English courses to EFL students who vary in language, culture, and beliefs,. These students comprise the multicultural and multilingual environment of AMA International University, Kingdom of Bahrain.

She has pursued several research endeavors and had presented them to both local and international conferences. 